\title{
Metal-ligand bonding in bispidine chelate complexes for radiopharmaceutical applications
}

\author{
Attila Kovács ${ }^{1}$ (1) \\ Received: 23 November 2021 / Accepted: 23 February 2022 / Published online: 3 March 2022 \\ (c) The Author(s) 2022
}

\begin{abstract}
The complexes of selected radionuclides relevant for nuclear medicine ( $\mathrm{II}^{\mathrm{III}}, \mathrm{Bi}^{\mathrm{III}}, \mathrm{Lu}^{\mathrm{III}}, \mathrm{Ac}^{\mathrm{III}}$ and in addition $\mathrm{La}^{\mathrm{III}}$ for comparative purposes) with the octadentate (6,6'-((9-hydroxy-1,5-bis(methoxycarbonyl)-2,4-di(pyridin-2-yl)-3,7-diazabicyclo[3.3.1] nonane-3,7-diyl)bis(methylene))dipicolinic acid) ligand, $\mathrm{H}_{2} \mathrm{bispa}^{2}$, have been studied by density functional theory calculations modelling both isolated and aqueous solution conditions. The properties in focus are the encapsulation efficiency of the ligand for the different-size metals $(\mathrm{M})$, the differences in bonding with the various $\mathrm{M}^{\mathrm{III}}$ ions analysed using Bader's atoms in molecules theory and the possibility and characteristics of nona- and decacoordination by $\mathrm{H}_{2} \mathrm{O}$ ligands. The computed results confirmed strong steric effects in the case of the In complex excluding higher than octacoordination. The studied properties depend strongly on the interplay of the sizes and electronic structures of the $\mathrm{M}^{\mathrm{III}}$ ions. The computations support high stability of the complexes in aqueous solution, where also the solvation energies of the $\mathrm{M}^{\mathrm{III}}$ ions (as dissociation products) play a significant role.
\end{abstract}

Keywords Radiopharmaceuticals $\cdot$ Bispa $\cdot$ Water addition $\cdot$ Coordination number $\cdot$ Bonding $\cdot$ Thermodynamic stability

\section{Introduction}

Radioisotopes are very efficient in treating cancer and other cases of abnormal tissue growth [1,2]. The method is based on ionizing radiation, which can break DNA molecules, preventing in this way their replication. In order to avoid a large-scale destruction of healthy tissues, the radiopharmaceuticals should be transferred directly to the diseased cells. For the same reason, preferably $\alpha$-emitting radioisotopes should be applied utilizing the short range of this radiation. The technique is called targeted- $\alpha$-therapy (TAT) and has only recently been introduced in clinical applications [2-11]. Accordingly, the field is still subjected to extensive research. A major issue is to find the most optimal transport agents for the various radioisotopes relevant for TAT. These transport agents are biological targeting vectors (antibody or peptides that have affinity for cancer cells) containing the

Dedicated to the memory of Richard F. W. Bader (1931-2012)!

Attila Kovács

attila.kovacs@ec.europa.eu

1 Joint Research Centre (JRC), European Commission, Karlsruhe, Germany radionuclide in chelated form [12]. The chelating agent has a key role in the process: an efficient transport requires highly stable chelate complexes with both the radiopharmaceutics and the (generally also radioactive) decay products to be departed from the body.

Bispidine ligands represent very promising chelating agents for radiopharmaceutical applications [13-15]. The rigid bispidine scaffold can be extended by a variety of donor sets using relatively simple synthetic routes. Ligands with coordination numbers ranging from 4 to 8 containing $\mathrm{O}$ and $\mathrm{N}$ donors have been reported [14-16]. Variation of the pendant groups resulted in specific bispidine ligands for a range of radiometal ions, showing high complex stability, inertness and fast complexation kinetics $[14,16]$. An additional advantage for medical applications is their simple conjugation to peptides or antibodies [17-21].

The excellent complexation properties of bispidines are due to the rigid diazaadamantyl backbone containing two preorganized tertiary amines and two pendant pyridine donors. Additional multidentate pendant groups can be attached to the tertiary amines facilitating efficient encapsulation of specific metal ions in their preferred coordination geometry [14, 22]. This is achieved by the pendant groups creating an elastic coordination sphere, where the 
metal ions can accomplish their preferred coordination numbers. The highly preorganized open-chain ligands can also facilitate fast complex formation.

Earlier radiopharmaceutical studies of bispidines have focussed on encapsulating $\mathrm{Cu}^{\mathrm{II}}\left({ }^{64 / 67} \mathrm{Cu}^{\mathrm{II}}\right.$ being a PET tracer) by penta- and hexadentate ligand systems [17, 23-27]. Recently, the octadentate bispa derivative, $\mathrm{H}_{2}$ bispa $^{2}$ (6,6'-((9-hydroxy-1,5-bis(methoxycarbonyl)-2,4di(pyridin-2-yl)-3,7-diazabicyclo[3.3.1]nonane-3,7-diyl) bis(methylene))dipicolinic acid) has been probed for larger radionuclides relevant for nuclear medicine $\left(\mathrm{In}^{\mathrm{III}}, \mathrm{Bi}^{\mathrm{III}}\right.$, $\mathrm{Lu}^{\mathrm{III}}$ and $\mathrm{La}^{\mathrm{III}}$ as surrogate for $\left.{ }^{225} \mathrm{Ac}^{\mathrm{III}}\right)[16,28]$. The latter experimental studies revealed high stabilities of the metal complexes and fast complex formation under ambient conditions. In addition, two isomeric picolinate-/acetatebased heptadentate bispa derivative ligands also showed very efficient complexation kinetics with $\mathrm{Bi}^{\mathrm{III}}$ at ambient temperature and kinetic stabilities comparable with those of standard ligands used in the field [28].

The present theoretical study aims to uncover the bonding characteristics of the $\mathrm{H}_{2}$ bispa $^{2}$ ligand with therapeutically relevant $\mathrm{In}^{\mathrm{III}}, \mathrm{Bi}^{\mathrm{III}}, \mathrm{Lu}^{\mathrm{III}}$ and $\mathrm{Ac}^{\mathrm{III}}$ cations (Fig. 1). In order to assess the effect of different electronic structures of lanthanides and main group metals, the complexes of $\mathrm{La}^{\mathrm{III}}$ and $\mathrm{Bi}^{\mathrm{III}}$ (having nearly the same ionic radii) are compared. The main questions include the encapsulation efficiency of the ligand for the different-size metals, the differences in bonding formed by the various metal ions and the effects of $\mathrm{H}_{2} \mathrm{O}$-coordination.

\section{Computational details}

The density functional theory (DFT) computations were carried out with the Gaussian 09 suit of programs [29]. On the basis of the reported good performance of the TPSSh meta-hybrid functional [30] for the molecular geometries and relative stabilities of various complexes [31-35], this functional was applied throughout the present study. The grid specification for the two-electron integrals was 150 radial shells and 974 angular points per shell $(150,974$; SuperFineGrid keyword) for H, C, N and O and $(225,974)$ for the heavier elements. For the self-consistent field (SCF) convergence, Tight criteria have been used corresponding to $1.00 \mathrm{E}-08$ in convergence on the RMS density matrix and $1.00 \mathrm{E}-06$ in energy change. The basis sets were selected on the basis of test calculations on the $\operatorname{In}\left(\mathrm{bispa}^{2}\right)^{+}$complex compared with the crystal structure of $\left[\operatorname{In}\left(\mathrm{bispa}^{2}\right)\right]$ [TFA] [16]. In the benchmark calculations for In, the largecore (LC) ECP46MWB [36] and small-core (SC) ECP28MDF [37] pseudopotentials in conjunction with valence basis sets of contraction schemes $(4 s 4 p) /(2 s 2 p)[36]$ and cc-pVDZ (8s6p6d)/(4s3p2d) or cc-pVTZ (12s11p9d1f)/ (5s4p3d1f) [38], respectively, were utilized. For the light atoms, the standard 6-31G(d,p) and 6-311G(d,p) bases extended eventually with diffuse functions on $\mathrm{N}$ and $\mathrm{O}$ were probed. The dispersion effects were considered using the empirical D3 parameters of Grimme et al. with the original D3 damping function [39] as well as with BeckeJohnson damping (D3BJ) [40].
Fig. 1 a The $\mathrm{H}_{2}$ bispa $^{2}$ ligand with numbering of the most relevant moieties; $\mathbf{b}$ structure of the $\mathrm{Bi}\left(\mathrm{bispa}^{2}\right)^{+}$complex $(\mathrm{Bi}$, violet; carbon, grey; oxygen, red; nitrogen, blue; hydrogens of bispa ${ }^{2}$ are removed for better visibility). The structure is gradually fainter towards the back

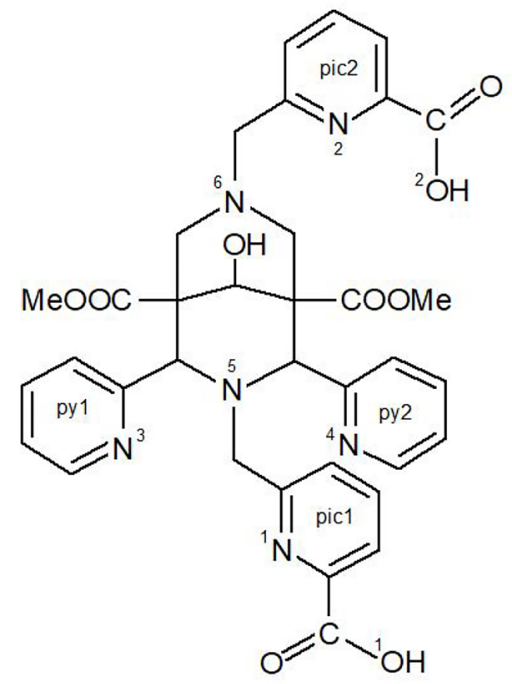

a)

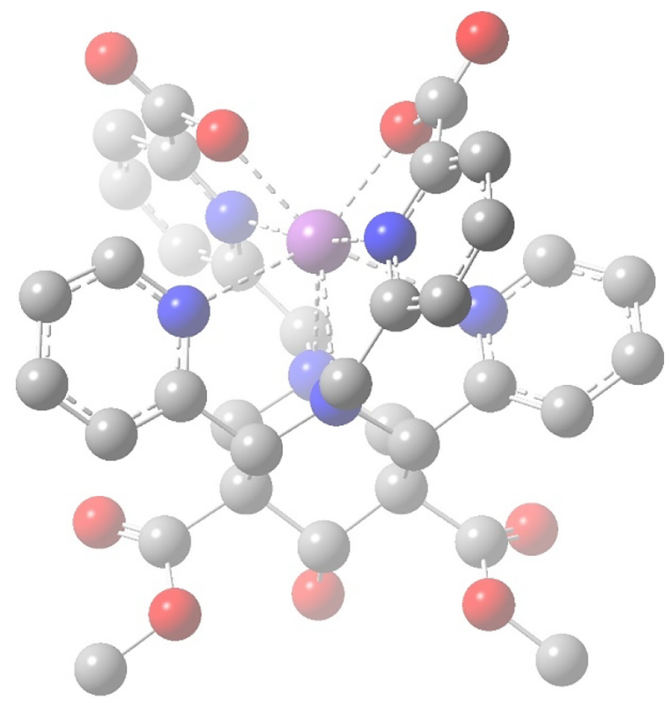

b) 
The performance of each probed computational level is assessed by comparing the X-ray diffraction and computed In-ligand distances in Table S1 of the Supplementary Information. The general feature of all tested levels is the underestimation of the M-O, and overestimation of the M-N distances with respect to the solid-phase data. Such deviations are understandable in view of the missing intermolecular interactions in the computed isolated molecules. Under the latter conditions, the strongly anionic carboxylate oxygens focus on the interaction with the metal ions and thus the overestimated $\mathrm{M}-\mathrm{O}$ bonds pull the metal away from the $\mathrm{N}$ donors.

On the basis of the above benchmark calculations, the SC pseudopotential was selected for the metals in conjunction with the $6-311(+) \mathrm{G}(\mathrm{d}, \mathrm{p})$ basis for the light atoms and the D3BJ dispersion correction. For the metals, this means the following pseudopotentials and valence basis sets: ECP60MDF + cc-pVTZ with $(12 \mathrm{~s} 11 \mathrm{p} 8 \mathrm{~d} 1 \mathrm{f}) /$ $(5 \mathrm{~s} 4 \mathrm{p} 3 \mathrm{~d} 1 \mathrm{f})$ contraction for $\mathrm{Bi}[37,38]$ and ECP$28 \mathrm{MWB}+(14 \mathrm{~s} 13 \mathrm{p} 10 \mathrm{~d} 8 \mathrm{f} 6 \mathrm{~g}) /(10 \mathrm{~s} 8 \mathrm{p} 5 \mathrm{~d} 4 \mathrm{f} 3 \mathrm{~g})$ valence basis for $\mathrm{La}$ and $\mathrm{Lu}[41,42]$. Unfortunately, severe SCF convergence problems occurred with the SC pseudopotential (ECP$60 \mathrm{MWB}+(14 \mathrm{~s} 13 \mathrm{p} 10 \mathrm{~d} 8 \mathrm{f} 6 \mathrm{~g} / 10 \mathrm{~s} 9 \mathrm{p} 5 \mathrm{~d} 4 \mathrm{f} 3 \mathrm{~g})$ valence basis $)$ of Ac $[43,44]$; therefore, for this metal, the large-core ECP$78 \mathrm{MWB}$ pseudopotential with the contracted $(7 \mathrm{~s} 6 \mathrm{p} 5 \mathrm{~d} 2 \mathrm{f} 1 \mathrm{~g}) /$ (6s5p4d2f1g) valence basis [45] set was used. In a recent study on Ac(macropa) complexes including both the SC and LC pseudopotentials for Ac [34], differences in the magnitude of $0.01 \AA$ in the metal-ligand distances and $50 \mathrm{~kJ} /$ mol in the dissociation energies were observed comparing the results obtained by the two Ac pseudopotentials. All the applied pseudopotentials here cover the scalar relativistic effects, which are particularly important for the heavy metals.

The geometries of all the studied complexes were optimized at the above levels of theory using default convergence criteria to a maximum step size of 0.0018 au and a maximum force of $0.00045 \mathrm{au}$. The minimum characters were confirmed by frequency calculations. For the free $\left(\text { bispa }^{2}\right)^{2-}$ ligand molecule, five conformations (selected by steric considerations) were optimized and the lowestenergy one was used in the evaluation of dissociation energies. The Cartesian coordinates of the optimized structures are given in the Supplementary Information. The quantum theory of atoms in molecules (QTAIM [46-48]) analysis was performed with the Multiwfn code using a medium-quality grid [49].

Dissociation energies were corrected for basis set superposition error (BSSE) using the counterpoise method [50]. The solvent effects were taken into account using the polarizable continuum model (PCM) [51, 52] with radii and non-electrostatic terms from the SMD solvation model by Marenich et al. [53]. For $\mathrm{La}^{3+}, \mathrm{Lu}^{3+}$ and $\mathrm{Ac}^{3+}$, the PCM radii from literature were used $(1.874 \AA$, $1.659 \AA$ [31] and
$1.933 \AA$ [34], respectively). For $\mathrm{In}^{3+}$ and $\mathrm{Bi}^{3+}$, no such radii are available; therefore, they were developed in the present study ( $1.507 \AA$ and $1.723 \AA$, respectively) on the basis of literature hydration free energies [54]. No scaling factor $(\alpha=1.0)$ was applied for the PCM radii in the present study. The solvation energies were evaluated in single-point calculations on the optimized geometries of the isolated molecules. Recently, a similar theoretical model reproduced excellently the experimental stability relations of lanthanide complexes [31].

In order to account for the reduction of the translation entropy of water molecules in aqueous solution, the water pressure was set to $1354 \mathrm{~atm}$ (value derived from the liquid water density of $997.02 \mathrm{~kg} / \mathrm{m}^{3}$ at $298 \mathrm{~K}$ ) instead of $1 \mathrm{~atm}$ $[55,56]$ in the calculation of its Gibbs free energy.

\section{Structural characteristics}

The bispa ${ }^{2}$ anionic ligand captures well the present metal ions in its cavity by means of eight coordinative metal-ligand bonds. (Unlike - in the past well-studied - $\mathrm{Cu}^{\mathrm{II}}[17,23-27]$, the sizes of the present metal ions are large enough for octacoordination.) The ligand coordination is achieved by the two deprotonated picolinate oxygens and the six nitrogens of bispa ${ }^{2}$ (cf. Fig. 1b). Accordingly, the isolated complex molecule without counterion has a single positive charge, $\mathrm{M}\left(\mathrm{bispa}^{2}\right)^{+}$.

As the donor-acceptor distances in Fig. 2 indicate, the strongest metal-ligand interaction is generally achieved with the anionic picolinate oxygens. In the case of the In complex (with the shortest $\mathrm{M}^{\mathrm{III}}$ ionic radius), the $\mathrm{M}-\mathrm{O}_{\text {pic }}$ and $\mathrm{M}-\mathrm{N}_{\text {pic }}\left(\mathrm{N}_{1}, \mathrm{~N}_{2}\right.$; cf. Fig. 1a) distances are comparable, while in the other $\mathrm{M}\left(\text { bispa }^{2}\right)^{+}$complexes, the $\mathrm{M}-\mathrm{O}_{\text {pic }}$ distances are considerably smaller than the $\mathrm{M}-\mathrm{N}_{\text {pic }}$ ones. In fact, the coordination of $\mathrm{N}_{\text {pic }}$ loses its importance with the larger metal ions, shown by the difference between $\mathrm{M}-\mathrm{O}_{\text {pic }}$ and $\mathrm{M}-\mathrm{N}_{\text {pic }}$ increasing in a larger extent than the $\mathrm{M}^{\mathrm{III}}$ size. In the La and Ac complexes, the M-N $\mathrm{N}_{\mathrm{pic}}$ bonds weaken almost to the level of the other nitrogens. In the case of $\operatorname{In}\left(\mathrm{bispa}^{2}\right)^{+}$, the $\mathrm{M}-\mathrm{O}_{\text {pic }}$ distances are larger than expected from the trend in the $\mathrm{M}^{\mathrm{III}}$ ionic radii [57]. The spatial requirements of the small $\mathrm{In}^{\mathrm{III}}$ ionic radius supported by the propensity of $\mathrm{In}^{\mathrm{III}}$ for short-range covalent interactions are mainly responsible for this compact arrangement of the picolinate groups. The more relaxed conditions in the other complexes allow the orientation of the picolinate groups guided by the anionic $\mathrm{O}_{\text {pic }}$ atoms. Another indication of the strong steric effects in the compact $\operatorname{In}\left(\mathrm{bispa}^{2}\right)^{+}$molecule is that the pyridine ring with $\mathrm{N}_{4}$ is crowded out from the close vicinity of In. The declination of this pyridine ring is somewhat larger in the crystal, where additional effects like crystal packing and intermolecular interactions are also possible. 
Fig. 2 Metal-ligand bond distances in the $\mathrm{M}\left(\text { bispa }^{2}\right)^{+}$ complexes compared to the $\mathrm{M}^{\mathrm{III}}$ effective ionic radii for 6 - and 8-coordination $(\AA)$ [57]. For the numbering of atoms, see Fig. 1a. The presented values are given in Table $\mathrm{S} 2$ of the Supplementary Information

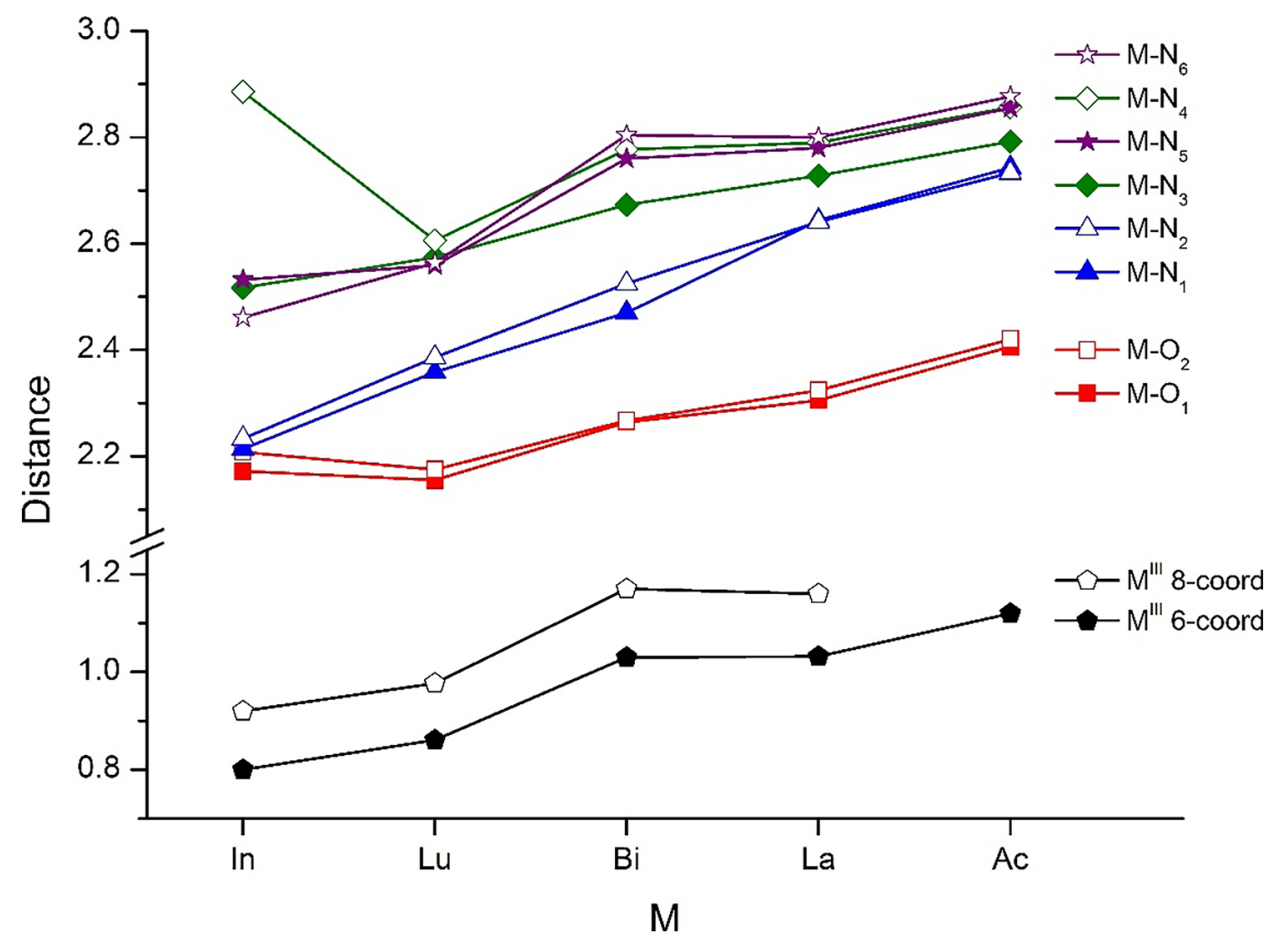

Comparing the trends across $\mathrm{M}$ in Fig. 2, the best agreement with the $\mathrm{M}^{\mathrm{III}}$ ionic radii can be observed for the weakest interactions with the bispidine nitrogens $\left(\mathrm{N}_{5}, \mathrm{~N}_{6}\right)$. M- $\mathrm{N}_{3}$ and $\mathrm{M}-\mathrm{N}_{1} / \mathrm{N}_{2}$ (increasing in a nearly straight line from In to Ac) do not seem to be sensitive to the small variations in the $\mathrm{M}^{\mathrm{III}}$ ionic radii. It should be noted that though the ionic radii of $\mathrm{Bi}^{\mathrm{III}}$ and $\mathrm{La}^{\mathrm{III}}$ are nearly the same, most of the presented distances suggest a stronger bonding of $\mathrm{Bi}$. This can be explained by the different bonding in the p-block (Bi) and f-block (La) elements. The main differences include the generally larger electronegativities of the p-block elements, hence a larger propensity for covalent bonding established by the valence $\mathrm{p}$ orbitals in contrast to the more ionic lanthanides.

\section{Saturation of the first coordination sphere with $\mathrm{H}_{2} \mathrm{O}$ molecules}

In the case of large captured metal ions, a coordinatively unsaturated space is available between the picolinate and pyridine groups (on the top side of Fig. 1b), where small molecules could additionally coordinate. Direct coordination of an $\mathrm{NO}_{3}{ }^{-}$ion to $\mathrm{Bi}^{\mathrm{III}}$ has been found in the crystal of $\left[\mathrm{Bi}\left(\right.\right.$ bispa $\left.\left.^{2}\right)\left(\mathrm{NO}_{3}\right)\right] \cdot \mathrm{H}_{2} \mathrm{O}$, while a replacement of $\mathrm{NO}_{3}^{-}$ions by solvent molecules in solution was consistent with NMR data [28]. Beyond this observed nonadentate coordination, the possibility of decadentate coordination was postulated by Bruchertseifer et al. [28]. The coordination of $\mathrm{H}_{2} \mathrm{O}$ at the molecular level was probed in the present study by optimizing the $\mathrm{M}\left(\right.$ bispa $\left.^{2}\right)\left(\mathrm{H}_{2} \mathrm{O}\right)^{+}$and $\mathrm{M}\left(\mathrm{bispa}^{2}\right)\left(\mathrm{H}_{2} \mathrm{O}\right)_{2}{ }^{+}$complexes for the five $\mathrm{M}^{\mathrm{III}}$ ions. The obtained characteristic structures of the nona- and decadentate complexes are shown in Fig. 3.

Both mono- and bicoordination of $\mathrm{H}_{2} \mathrm{O}$ were obtained for the present $\mathrm{M}^{\mathrm{III}}$ ions except for $\mathrm{In}^{\mathrm{III}}$. The bispa ${ }^{2}$ ligand surrounds this latter small ion completely and does not leave sufficient space for coordination of $\mathrm{H}_{2} \mathrm{O}$. The starting $\mathrm{In}\left(\mathrm{bispa}^{2}\right)\left(\mathrm{H}_{2} \mathrm{O}\right)^{+}$and $\mathrm{In}\left(\mathrm{bispa}^{2}\right)\left(\mathrm{H}_{2} \mathrm{O}\right)_{2}{ }^{+}$structures derived from the $\mathrm{Lu}\left(\mathrm{bispa}^{2}\right)\left(\mathrm{H}_{2} \mathrm{O}\right)^{+}$and $\mathrm{Lu}\left(\mathrm{bispa}^{2}\right)\left(\mathrm{H}_{2} \mathrm{O}\right)_{2}{ }^{+}$ones changed upon geometry optimization to $\operatorname{In}\left(\mathrm{bispa}^{2}\right)^{+}$with the $\mathrm{H}_{2} \mathrm{O}$ ligands moving into the second coordination sphere and hydrogen-bonded to the picolinate oxygens.

The lack of (even one) $\mathrm{H}_{2} \mathrm{O}$-coordination to $\mathrm{In}\left(\mathrm{bispa}^{2}\right)^{+}$ seems to be strange in the view of the 8 -coordinate In $^{\text {III }}$ ionic radius being smaller only by $0.06 \AA$ than that of $\mathrm{Lu}^{\mathrm{III}}$. In order to understand this significant difference between $\operatorname{In}\left(\mathrm{bispa}^{2}\right)^{+}$and the other complexes, the cavities around the picolinate arms need to be analysed in detail.

There are two small cavities of similar size in this space section defined by the heteroatoms $\mathrm{O}_{1}, \mathrm{~N}_{2}, \mathrm{~N}_{4}$ and $\mathrm{O}_{2}, \mathrm{~N}_{1}, \mathrm{~N}_{3}$, respectively. The two cavities are separated by the $\mathrm{M}-\mathrm{O}_{1}$ and $\mathrm{M}-\mathrm{O}_{2}$ bonds. They are the strongest coordinative interactions (due to these anionic oxygens) in the bispa ${ }^{2}$ complexes, and consequently quite rigid. Due to that, the cavities are essentially independent from each other. Coordination of additional ligands at these sites is restricted by the sizes of these independent cavities. One cavity cannot gain space for the cost of the other, and they cannot merge to a single large cavity either (without breaking of the M-O bonds). Hence, 


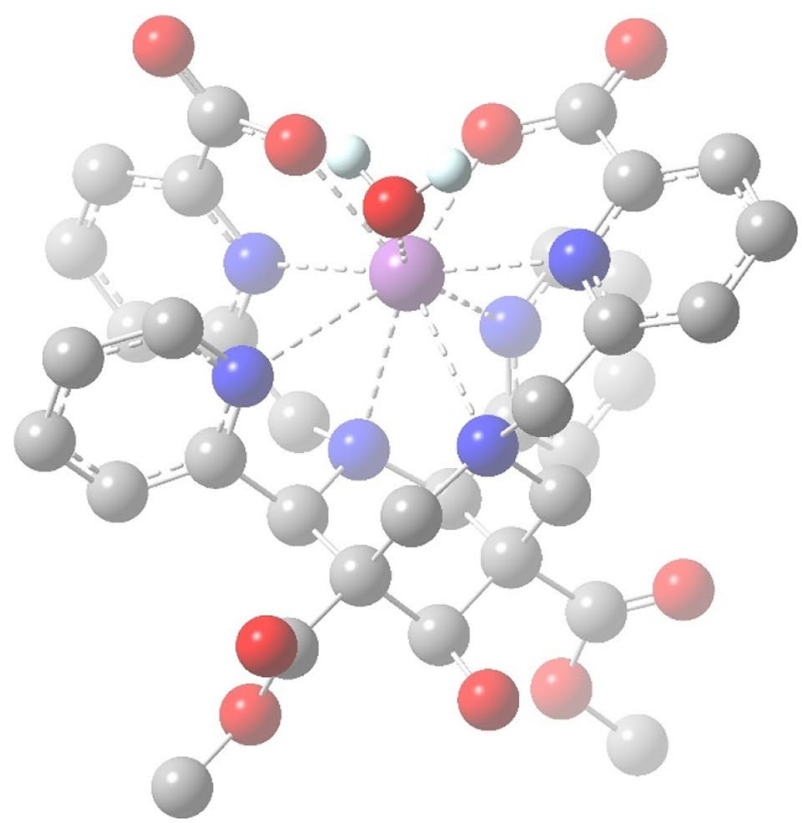

a)

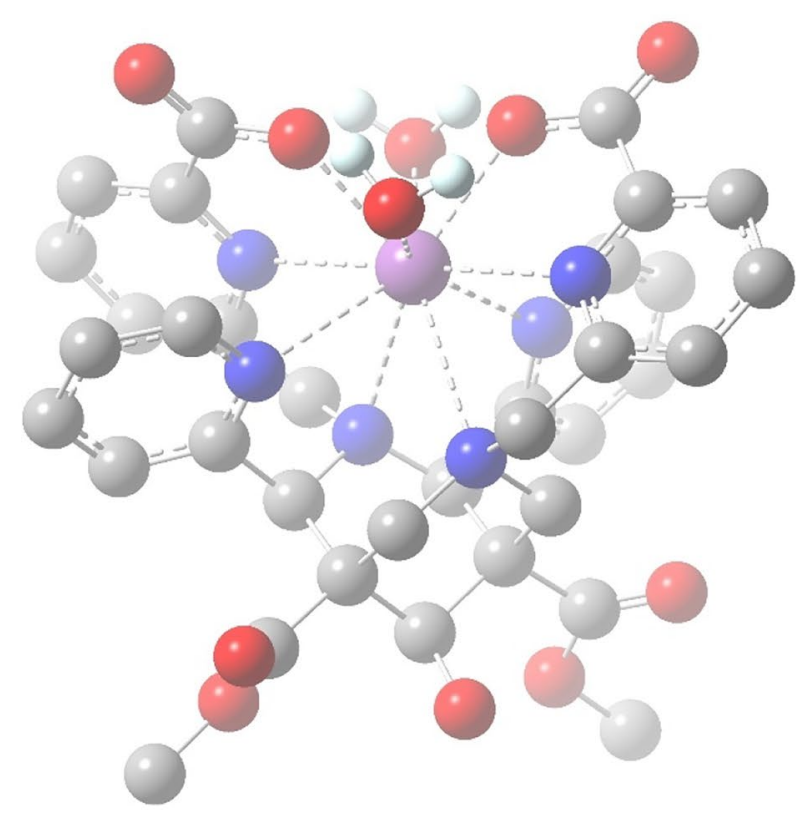

b)

Fig. 3 Structure of the a $\mathrm{Bi}\left(\mathrm{bispa}^{2}\right)\left(\mathrm{H}_{2} \mathrm{O}\right)^{+}$and $\mathbf{b} \mathrm{Bi}\left(\mathrm{bispa}^{2}\right)\left(\mathrm{H}_{2} \mathrm{O}\right)_{2}{ }^{+}$complexes ( $\mathrm{Bi}$, violet; carbon, grey; oxygen, red; nitrogen, blue; hydrogen, white; hydrogens of bispa $^{2}$ are removed for better visibility). The structure is gradually fainter towards the back

if the cavity is too small for coordinating $\mathrm{H}_{2} \mathrm{O}$, a monocoordination is not possible either.

The sizes of these cavities are best characterized by the $\mathrm{O}_{1}-\mathrm{N}_{2}$ and $\mathrm{O}_{2}-\mathrm{N}_{1}$ distances. These heteroatoms have the shortest inter-heteroatom distances as well as the shortest coordinative bonds to the central metal ion. The coordinating $\mathrm{H}_{2} \mathrm{O}$ ligand is in their vicinity (cf. Fig. 4); hence, its contact to them is of paramount importance. In the $\mathrm{Lu}\left(\mathrm{bispa}^{2}\right)\left(\mathrm{H}_{2} \mathrm{O}\right)_{2}{ }^{+}$complex, the $\left(\mathrm{H}_{2}\right) \mathrm{O} \ldots \mathrm{O}_{\text {pic }}$ and $\left(\mathrm{H}_{2}\right) \mathrm{O} \ldots \mathrm{N}_{\text {pic }}$ non-bonding distances are around 2.46 and $2.71 \AA$, respectively. This facilitates $\mathrm{Lu}-\mathrm{O}\left(\mathrm{H}_{2}\right)$ bonding distances of around $2.57 \AA$. The steric interactions would require similar $\left(\mathrm{H}_{2}\right) \mathrm{O} \ldots \mathrm{O}_{\text {pic }}$ and $\left(\mathrm{H}_{2}\right) \mathrm{O} \ldots \mathrm{N}_{\text {pic }}$ non-bonding distances in the $\mathrm{In}\left(\mathrm{bispa}^{2}\right)\left(\mathrm{H}_{2} \mathrm{O}\right)^{+}$complex too. Due to the proximity of picoline $\mathrm{O}$ and $\mathrm{N}$ atoms in the more compact $\operatorname{In}\left(\text { bispa }^{2}\right)^{+}$complex, however, these steric interactions force the $\mathrm{H}_{2} \mathrm{O}$ oxygen to a very large distance from $\mathrm{In}^{\mathrm{III}}$ (in the present theoretical model to around $3.8 \AA$ ), being too far for a coordinative bonding with the small $\mathrm{In}^{\mathrm{III}}$ ion.

The $\mathrm{M}^{\mathrm{III}}-\mathrm{O}\left(\mathrm{H}_{2}\right)$ coordinative distances are compiled together with the O...N inter-picoline distances in Fig. 5. The steep increase of the latter parameter from In towards the larger metals can justify the found $\mathrm{H}_{2} \mathrm{O}$-coordination to $\mathrm{Lu}\left(\mathrm{bispa}^{2}\right)^{+}$in contrast to $\operatorname{In}\left(\mathrm{bispa}^{2}\right)^{+}$. The relaxed surroundings with increasing cavities can be followed in the $\mathrm{M}-\mathrm{O}\left(\mathrm{H}_{2}\right)$ distances. While in the case of Lu(bispa $\left.{ }^{2}\right)$ $\left(\mathrm{H}_{2} \mathrm{O}\right)_{2}{ }^{+}$the $\mathrm{H}_{2} \mathrm{O}$ ligand coordinating in the smaller cavity has an $\mathrm{M}-\mathrm{O}\left(\mathrm{H}_{2}\right)$ distance larger by $0.15 \AA$ than that in the larger cavity, in the Ac and La complexes the two $\mathrm{M}-\mathrm{O}\left(\mathrm{H}_{2}\right)$ distances are practically the same and agree also

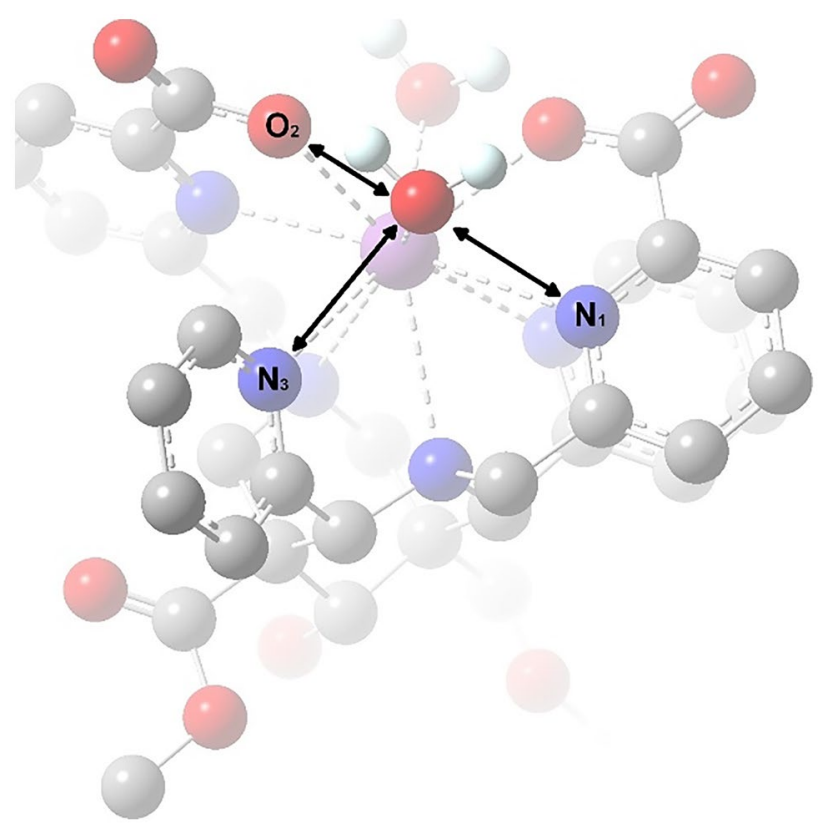

Fig. 4 Perspective view of the cavity defined by the $\mathrm{O}_{2}, \mathrm{~N}_{1}, \mathrm{~N}_{4}$ heteroatoms in the $\mathrm{Bi}\left(\mathrm{bispa}^{2}\right)^{+}$complex. The structure is gradually fainter towards the back 
Fig. $5 \mathrm{O}_{1} \ldots \mathrm{N}_{2}$ and $\mathrm{O}_{2} \ldots$ $\mathrm{N}_{1}$ inter-picoline distances in the $\mathrm{H}_{2} \mathrm{O}$-free complexes and $\mathrm{M}-\mathrm{O}\left(\mathrm{H}_{2}\right)$ distances in the $\mathrm{M}\left(\mathrm{bispa}^{2}\right)\left(\mathrm{H}_{2} \mathrm{O}\right)_{\mathrm{x}}{ }^{+}(\mathrm{x}=1,2)$ complexes $(\AA)$. The presented values are given in Table $\mathrm{S} 2$ of the Supplementary Information

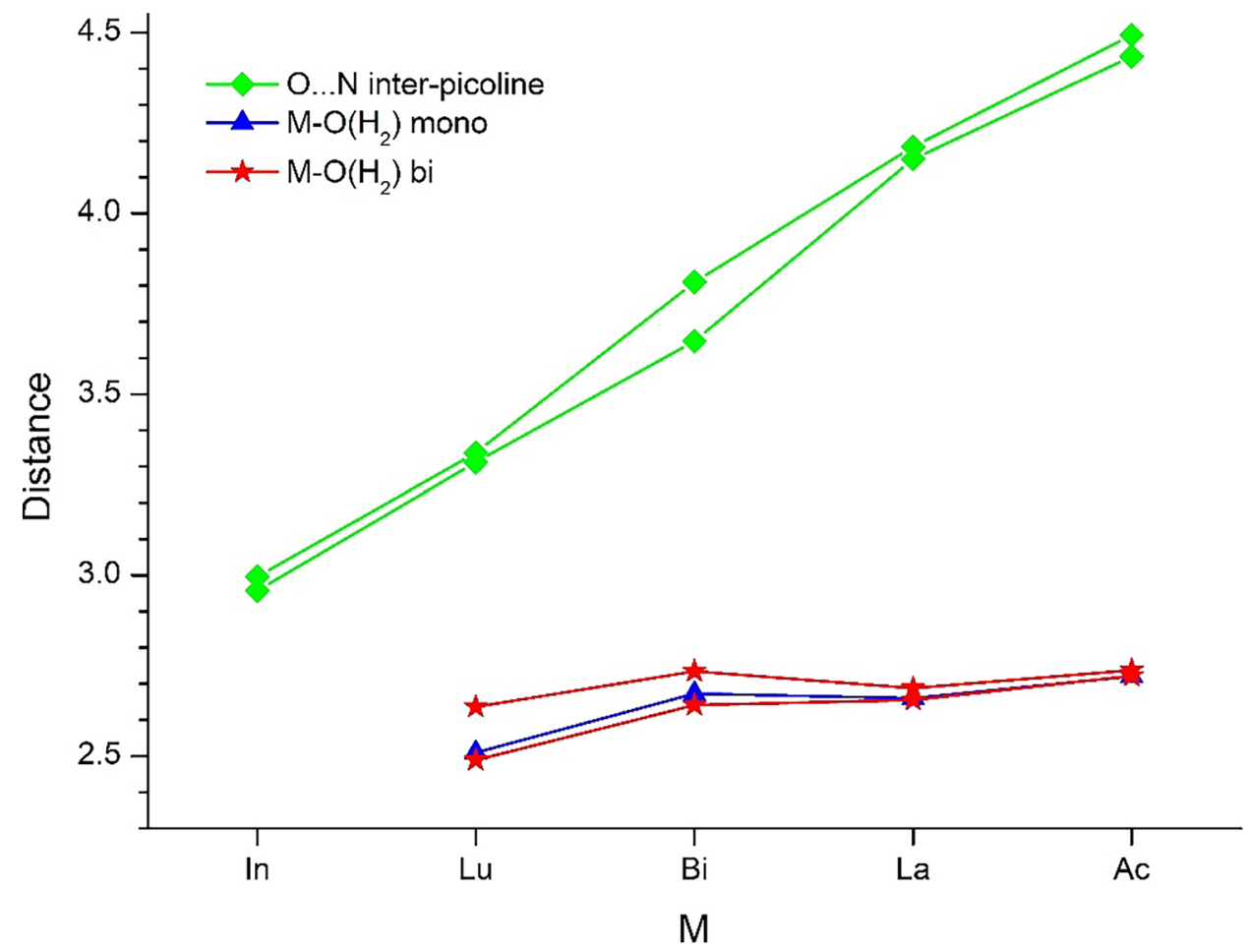

with that in the mono- $\mathrm{H}_{2} \mathrm{O}$ complex. The large cavity of $\mathrm{Ac}\left(\text { bispa }^{2}\right)^{+}$was probed for a third $\mathrm{H}_{2} \mathrm{O}$-coordination, but this extra $\mathrm{H}_{2} \mathrm{O}$ moved to the second coordination sphere upon geometry optimization.

The metal-ligand bond distances of the $\mathrm{M}\left(\mathrm{bispa}^{2}\right)$ $\left(\mathrm{H}_{2} \mathrm{O}\right)_{\mathrm{x}}{ }^{+}(\mathrm{x}=0-2)$ complexes are compiled in Table S2 while selected ones are given in Fig. S1 of the Supplementary Information. The distance of the $\mathrm{H}_{2} \mathrm{O}$ ligands from $\mathrm{M}$ falls in the magnitude of the $\mathrm{M}-\mathrm{N}_{\text {pic,py }}$ distances. From the two cavities of $\mathrm{bispa}^{2}$, the one including $\mathrm{N}_{5}$ is smaller, hence sterically less advantageous. Accordingly, the $\mathrm{H}_{2} \mathrm{O}$ ligand coordinates here with a larger $\mathrm{M}-\mathrm{O}\left(\mathrm{H}_{2}\right)$ distance. Due to this steric effect, from the two mono- $\mathrm{H}_{2} \mathrm{O}$ isomers the one with $\mathrm{H}_{2} \mathrm{O}$-coordination in the larger cavity is preferred.

As a general steric effect of the $\mathrm{H}_{2} \mathrm{O}$-coordination, the metal-bispa ${ }^{2}$ bonds are somewhat increased (empty symbols in Fig. S1). The increase is most pronounced in the Lu complex with the smallest relevant $\mathrm{M}^{\mathrm{III}}$ ionic radius.

\section{Bonding on the basis of QTAIM analysis}

The electrostatic and covalent contributions to the metalligand interactions in the $\mathrm{M}\left(\mathrm{bispa}^{2}\right)\left(\mathrm{H}_{2} \mathrm{O}\right)_{\mathrm{x}}{ }^{+}(\mathrm{x}=0-2)$ complexes are assessed on the basis of the Bader atomic charges and delocalization indices, evaluated using the quantum theory of atoms in molecules (QTAIM [46-48]). The Bader charges of $\mathrm{M}$ and $\mathrm{O}_{1}$ are given in Table 1; additional data are given in Table S3 of the Supplementary Information. These atoms (including the other analogous picolinate oxygen, $\mathrm{O}_{2}$ ) are the most sensitive on the differences in the various complexes. The atomic charges of the nitrogens change within 0.03 e and show no clear trend in their variations.

The metal charges can be grouped into three groups according to the character of the metal, reflected also by their electronegativities. The p-block In and $\mathrm{Bi}$ (with
Table 1 QTAIM (Bader) charges of selected atoms in the $\mathrm{M}\left(\right.$ bispa $\left.^{2}\right)\left(\mathrm{H}_{2} \mathrm{O}\right)_{\mathrm{x}}{ }^{+}(\mathrm{x}=0-2)$ complexes (e)

\begin{tabular}{|c|c|c|c|c|c|c|c|}
\hline \multirow[t]{2}{*}{ M } & \multirow[t]{2}{*}{$\mathrm{EN}^{\mathrm{a}}$} & \multicolumn{2}{|c|}{$\mathrm{M}\left(\mathrm{bispa}^{2}\right)^{+}$} & \multicolumn{2}{|c|}{$\mathrm{M}\left(\mathrm{bispa}^{2}\right)\left(\mathrm{H}_{2} \mathrm{O}\right)^{+}$} & \multicolumn{2}{|c|}{$\mathrm{M}\left(\mathrm{bispa}^{2}\right)\left(\mathrm{H}_{2} \mathrm{O}\right)_{2}{ }^{+}$} \\
\hline & & $\mathrm{q}_{\mathrm{M}}$ & $\mathrm{q}_{\mathrm{O} 1}$ & $\mathrm{q}_{\mathrm{M}}$ & $\mathrm{q}_{\mathrm{O} 1}$ & $\mathrm{q}_{\mathrm{M}}$ & qo1 \\
\hline $\mathrm{Bi}$ & 1.67 & 1.84 & -1.15 & 1.87 & -1.18 & 1.90 & -1.18 \\
\hline In & 1.49 & 1.82 & -1.18 & - & - & - & - \\
\hline $\mathrm{Lu}$ & 1.14 & 2.14 & -1.20 & 2.16 & -1.22 & 2.20 & -1.22 \\
\hline $\mathrm{La}$ & 1.08 & 2.14 & -1.20 & 2.16 & -1.22 & 2.17 & -1.22 \\
\hline Ac & 1.00 & 2.28 & -1.23 & 2.30 & -1.24 & 2.30 & -1.24 \\
\hline
\end{tabular}

${ }^{a}$ Allred-Rochow electronegativity of M in Pauling units [58, 59] 
larger electronegativities, thus propensities for covalent bonding) have the smallest positive charges in the studied complexes, while Ac (with the smallest electronegativity, having a strong preference for ionic bonding) has the largest positive charge. The atomic charges being around +2 confirm the electrostatic interactions being the major contributions in the bonding, as expected from the strong anionic $\left(-2\right.$ e) character of the bispa ${ }^{2}$ ligand too. The anionic character is manifested in the Bader charges of the picolinate oxygens (around-1.2 e) at the first place, being in the closest contact with the metal cations. Accordingly, the $\mathrm{O}_{1}$ (and the similar $\mathrm{O}_{2}$ ) charges roughly follow the variations in the metal charges. The pyridine $\mathrm{N}$ charges are also around $-1.2 \mathrm{e}$ (showing only slight variations) while $\mathrm{N}_{5}$ and $\mathrm{N}_{6}$ in the bispidine scaffold have somewhat lower values (around $-1.0 \mathrm{e}$ ).

The strongest charge transfer $(\mathrm{CT})$ to the $\mathrm{M}^{\mathrm{III}}$ ions occurs to the p-block metals (In, Bi), their low-energy valence $\mathrm{p}$ orbitals being excellent acceptor orbitals. The higher-energy $5 \mathrm{~d} / 6 \mathrm{~s}$ (mixed with $4 \mathrm{f}$ in the case of La) orbitals of the lanthanides can gain less from CT, while the weakest CT interaction is managed by the even higher-energy valence orbitals of Ac.

The $\mathrm{H}_{2} \mathrm{O}$ ligands transfer only marginal charge (up to 0.06 e) to the $\mathrm{M}^{\mathrm{III}}$ ions in the $\mathrm{M}\left(\mathrm{bispa}^{2}\right)\left(\mathrm{H}_{2} \mathrm{O}\right)_{\mathrm{x}}{ }^{+}(\mathrm{x}=1-2)$ complexes (cf. Table S4). Hence, the bispa ${ }^{2}$ ligand is the main contributor to the covalent bonding (in form of donor-acceptor interactions) in the complexes. The coordination of $\mathrm{H}_{2} \mathrm{O}$ increases slightly the magnitude of the $\mathrm{M}$ and $\mathrm{O}_{1}$ charges (cf. Table 1). This can be explained by the above shown increased M-bispa ${ }^{2}$ distances, which result in less CT from bispa $^{2}$ to $\mathrm{M}$.

Another computed parameter characterizing the covalent interactions in the complexes is the delocalization index. This integral property estimates the number of electrons forming the covalent bonding between $\mathrm{M}$ and the donor atoms of the ligands (and in this way the covalent bond order). Delocalization indices between $\mathrm{M}$ and the donor heteroatoms in the $\mathrm{M}\left(\mathrm{bispa}^{2}\right)^{+}$complexes are depicted in Fig. 6 (the depicted values are compiled in Table S5 together with those of the hydrated derivatives).

It should be noted that Fig. 6 does not reflect the energetics of covalent interactions, because it depends on the energies of the acceptor orbitals too. The smaller metals have lower-energy acceptor orbitals, where the same number of shared electrons results in a stronger covalent bonding in terms of energy. In addition, Fig. 6 is only roughly related to the bispa ${ }^{2}$-to-M CT, because part of the transferred M valence electron densities are localized in the appropriate $\mathrm{M}$ orbitals and do not take part in electron sharing interactions.

The main message of the data in Fig. 6 is the contribution of the various donor heteroatoms to the covalent bonding between $\mathrm{M}$ and $\mathrm{bispa}^{2}$. Thus, the major donor is the picolinate oxygen $\left(\mathrm{O}_{1}, \mathrm{O}_{2}\right)$, in the case of In comparable with the picolinate nitrogens $\left(\mathrm{N}_{1}, \mathrm{~N}_{2}\right)$. The latter donors have a considerable (towards Ac decreasing) contribution in the other complexes, too. The pyridine nitrogens $\left(\mathrm{N}_{3}, \mathrm{~N}_{4}\right)$ have comparable contributions to those of the bispidine scaffold except for the In complex, where the pyridine group containing $\mathrm{N}_{4}$ is crowded out from the sterically strained vicinity of In
Fig. 6 Delocalization indices (e) between $\mathrm{M}$ and the donor heteroatoms in the $\mathrm{M}\left(\mathrm{bispa}^{2}\right)^{+}$ complexes. Contributions from the analogous donors are summed up. The presented values are given in Table S5 of the Supplementary Information

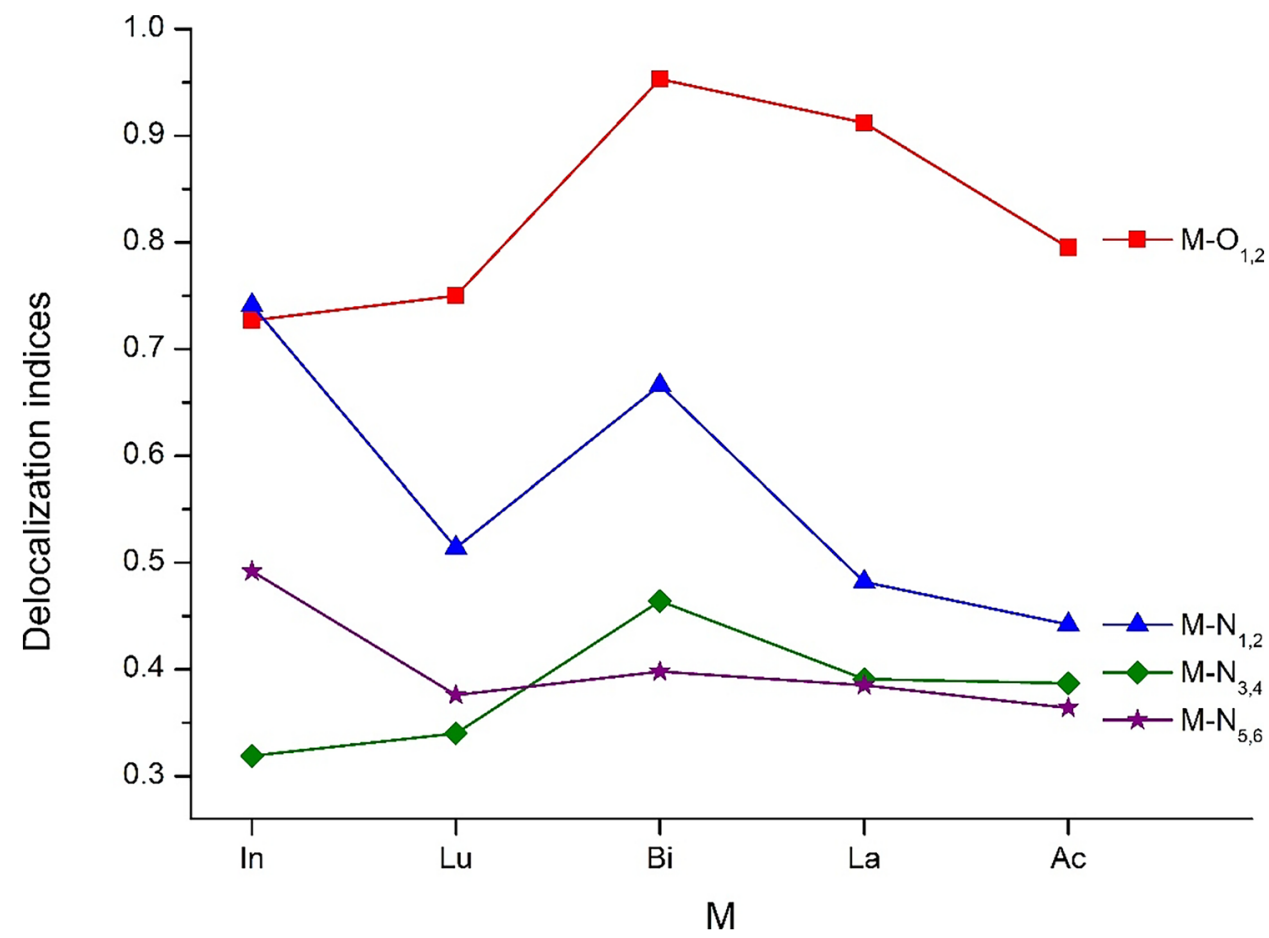


(vide supra). The main features in the curves of Fig. 6 are in fair correlation with the bond distances presented in Fig. 2. Due to the slightly increased bond distances in the hydrated $\mathrm{M}\left(\right.$ bispa $\left.^{2}\right)\left(\mathrm{H}_{2} \mathrm{O}\right)_{\mathrm{x}}{ }^{+}(\mathrm{x}=1-2)$ complexes, those delocalization indices are slightly smaller (cf. Table S5). The delocalization indices between $\mathrm{M}$ and the $\mathrm{H}_{2} \mathrm{O}$ ligands are comparable to those of the bispidine nitrogens. In the $\mathrm{M}-\mathrm{O}\left(\mathrm{H}_{2}\right)$ bonding, the covalent interaction seems to be a minor bonding contribution, because the $\mathrm{H}_{2} \mathrm{O}$ oxygen has a high negative charge (cf. Table S3).

\section{Energetics}

The computed stabilities of the $\mathrm{M}\left(\mathrm{bispa}^{2}\right)\left(\mathrm{H}_{2} \mathrm{O}\right)_{\mathrm{x}}{ }^{+}(\mathrm{x}=0-2)$ complexes are demonstrated by the dissociation energetics in Fig. 7 in terms of electronic energies of the isolated molecules as well as Gibbs free energies in aqueous solution at $298 \mathrm{~K}$. The corresponding data as well as energies of metal-metal exchange reactions are given in Tables S6 and S7, respectively, of the Supplementary Information.

The trend in Fig. 7a corresponds to a decreasing stability of the bispa ${ }^{2}$ complexes with increasing $\mathrm{M}^{\mathrm{III}}$ size in the case of the isolated molecule model. The gradual decrease deviates at the Bi complexes and may be attributed to the relatively stronger covalent bonding in them (cf. Fig. 6). The coordinating $\mathrm{H}_{2} \mathrm{O}$ molecules (missing for In, vide supra) contribute to the stability of the complexes with all the metals. This can be seen in both the larger total dissociation energies and the endothermic dissociation of the $\mathrm{H}_{2} \mathrm{O}$

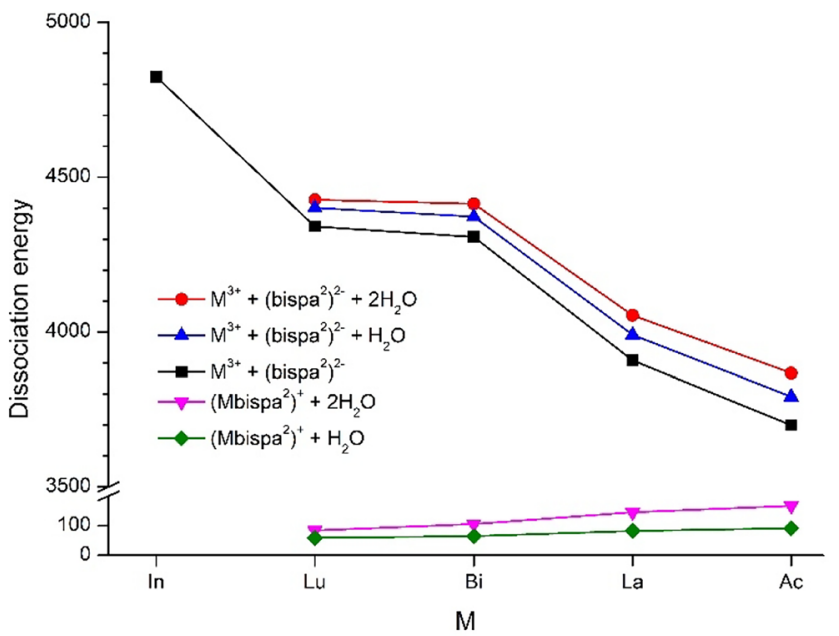

a)

Fig. 7 Dissociation energies $(\mathrm{kJ} / \mathrm{mol})$ of the $\mathrm{M}\left(\mathrm{bispa}^{2}\right)\left(\mathrm{H}_{2} \mathrm{O}\right)_{\mathrm{x}}{ }^{+}(\mathrm{x}=0-2)$ complexes to the presented dissociation products in terms of a BSSEcorrected electronic energy of the isolated molecules at $0 \mathrm{~K}$ and $\mathbf{b}$ BSSE- molecules with dissociation energies between 50 and $170 \mathrm{~kJ} /$ mol. The stability of $\mathrm{H}_{2} \mathrm{O}$-coordination increases with the $\mathrm{M}^{\mathrm{III}}$ size parallel with that of the cavities in $\mathrm{H}_{2} \mathrm{O}$-free $\mathrm{M}\left(\text { bispa }^{2}\right)^{+}$.

The situation changes drastically in the aqueous solution at $298 \mathrm{~K}$ (Fig. 7b). First, the dissociation energies are considerably smaller due to the strong stabilizing effect on the ionic dissociation products by the polar water solvent [60-62]. Second, the dissociation of the $\mathrm{H}_{2} \mathrm{O}$ ligands becomes slightly exothermic upon thermal energy and solvation effects. This is in agreement with the observed $\mathrm{H}_{2} \mathrm{O}$-exchange in solution [28]. Also the stability of the $\mathrm{M}\left(\right.$ bispa $\left.^{2}\right)\left(\mathrm{H}_{2} \mathrm{O}\right)_{\mathrm{x}}{ }^{+}$complexes is considerably decreased, particularly those of In and Lu with the smallest ionic radii. These small $\mathrm{M}^{\mathrm{III}}$ ions have very high solvation energies in water, and this larger stabilization of solvated In $^{\text {III }}$ and Lu ${ }^{\text {III }}$ ions as dissociation products supports the dissociation of the parent complexes. The destabilized $\mathrm{H}_{2} \mathrm{O}$-coordination under these conditions decreases the total dissociation energies of the $\mathrm{M}\left(\mathrm{bispa}^{2}\right)\left(\mathrm{H}_{2} \mathrm{O}\right)_{\mathrm{x}}{ }^{+}(\mathrm{x}=1,2)$ complexes below those of the $\mathrm{M}\left(\mathrm{bispa}^{2}\right)^{+}$ones, too.

It should be noted that the dissociation energies are likely underestimated by the LC pseudopotential of Ac. In a recent study of the Ac(macropa) complex [34], underestimation by 50 and $48 \mathrm{~kJ} / \mathrm{mol}$ was found for the electronic (in vacuum) and Gibbs free energies (in solution) of dissociation by the LC pseudopotential (unpublished results). An underestimation in this magnitude would not change the trends in Fig. 7, whereas it would predict a stability of the solvated Ac(bispa $\left.{ }^{2}\right)$ complex significantly closer to those of La.

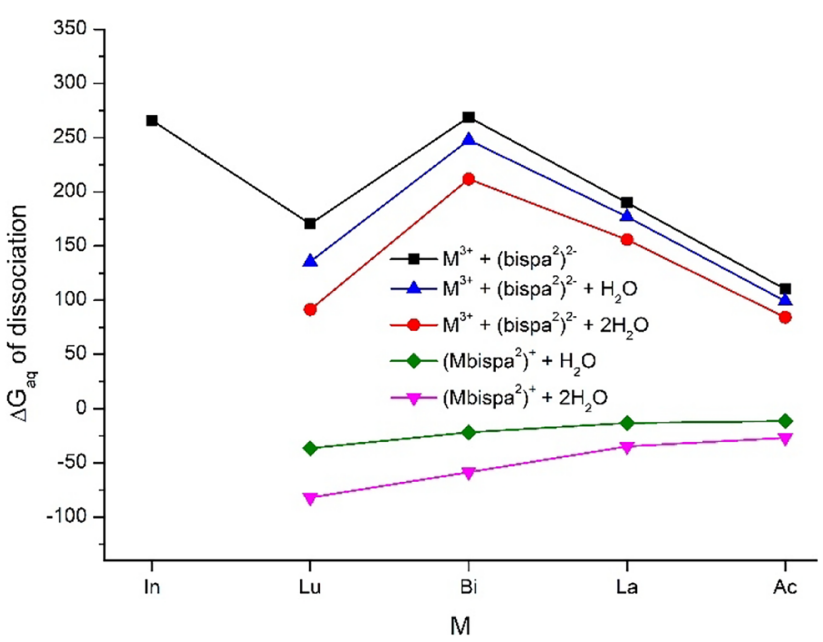

b) corrected Gibbs free energies in aqueous solution at $298 \mathrm{~K}$. The presented values are given in Table S6 of the Supplementary Information 
Altogether, supporting recent experimental observations $[16,28]$, the computations resulted in high stabilities of the bispa $^{2}$ complexes in aqueous solution for all the five studied metals. The computed stability order of $\mathrm{In}^{\mathrm{III}} \gg \mathrm{La}^{\mathrm{III}}>\mathrm{Lu}^{\mathrm{III}}$ for their bispa ${ }^{2}$ complexes is in agreement with experimental stability constants determined by potentiometric titrations [16].

\section{Conclusions}

In the paper, a theoretical study of complexes of radionuclides relevant for nuclear medicine $\left(\mathrm{In}^{\mathrm{III}}, \mathrm{Bi}^{\mathrm{III}}, \mathrm{Lu}^{\mathrm{III}}, \mathrm{Ac}^{\mathrm{III}}\right.$ and additionally $\mathrm{La}^{\mathrm{III}}$ ) with the octadentate bispa derivative, $\mathrm{H}_{2} \mathrm{bispa}^{2}$, is reported. The study was performed by means of density functional theory calculations modelling both the isolated molecules and aqueous solution conditions.

The theoretical level was chosen on the basis of previous good experience with the TPSSh meta-hybrid functional [31-35] and test calculations on the $\operatorname{In}\left(\mathrm{bispa}^{2}\right)^{+}$complex compared with the crystal structure of $\left[\operatorname{In}\left(\mathrm{bispa}^{2}\right)\right][$ TFA] [16]. As a result of the tests, relativistic pseudopotentials for the metals in conjunction with valence triple-zeta bases and the $\mathrm{D} 3 \mathrm{BJ}$ dispersion correction were selected.

The deprotonated ligand formed octadentate $\mathrm{M}\left(\mathrm{bispa}^{2}\right)^{+}$ complexes with all the metals covered in the present study. The encapsulation proved to be complete for $\mathrm{In}^{\mathrm{III}}$, leaving not enough space for additional coordination of a $\mathrm{H}_{2} \mathrm{O}$ ligand. The larger size of the other metals, however, facilitated the coordination of two $\mathrm{H}_{2} \mathrm{O}$ molecules resulting in decadentate $\mathrm{M}\left(\mathrm{bispa}^{2}\right)\left(\mathrm{H}_{2} \mathrm{O}\right)_{2}{ }^{+}$complexes. The bonding of these $\mathrm{H}_{2} \mathrm{O}$ ligands belongs to the weakest in these complexes, comparable to those of the bispidine nitrogens. From the eight heteroatoms of $\mathrm{bispa}^{2}$, the anionic picolinate oxygens play the main role in both the (major) ionic and (minor) covalent metal-ligand interactions.

The stability of the isolated complex molecules at $0 \mathrm{~K}$ follows the size of the metal, decreasing from In to Ac. In aqueous solution under ambient conditions, the In and $\mathrm{Bi}$ complexes are the most stable, having comparable stability. Close stability was obtained for the $\mathrm{Lu}$ and La complexes, while the Ac complex remained the least stable. The high solvation energies of $\mathrm{In}^{\mathrm{III}}$ and $\mathrm{Lu}^{\mathrm{III}}$ may be particularly responsible for the break of the trend mentioned above for the isolated molecules: the stabilization of these dissociation products supports the dissociation of their parent complexes with respect to the others.

Supplementary information The online version contains supplementary material available at https://doi.org/10.1007/s11224-022-01902-6.

Funding The calculations have been carried out using resources provided by the affiliation of the author.
Availability of data and material Benchmark calculations on In $\left(\text { bispa }^{2}\right)^{+}$, the values depicted in Figs. 1-7, metal-metal exchange energies, additional Bader atomic charges and Cartesian coordinates of the optimized structures are available as electronic supplementary material.

\section{Declarations}

Ethics approval The ethical standards have been met.

Conflict of interest The author declares no competing interests.

Open Access This article is licensed under a Creative Commons Attribution 4.0 International License, which permits use, sharing, adaptation, distribution and reproduction in any medium or format, as long as you give appropriate credit to the original author(s) and the source, provide a link to the Creative Commons licence, and indicate if changes were made. The images or other third party material in this article are included in the article's Creative Commons licence, unless indicated otherwise in a credit line to the material. If material is not included in the article's Creative Commons licence and your intended use is not permitted by statutory regulation or exceeds the permitted use, you will need to obtain permission directly from the copyright holder. To view a copy of this licence, visit http://creativecommons.org/licenses/by/4.0/.

\section{References}

1. Stewart AJ, Cormack RA, Held KD (2015) Radiobiologic concepts for brachytherapy. In: Devlin P, Cormack RA, Holloway CL, Stewart AJ (eds) Brachytherapy. Applications and techniques. Springer Publishing Company, New York, pp 37-52. https://doi. org/10.1891/9781617052613.0002

2. Kostelnik TI, Orvig C (2019) Radioactive main group and rare earth metals for imaging and therapy. Chem Rev 119(2):902-956. https://doi.org/10.1021/acs.chemrev.8b00294

3. Miederer M, Scheinberg DA, McDevitt MR (2008) Realizing the potential of the actinium-225 radionuclide generator in targeted alpha particle therapy applications. Adv Drug Delivery Rev 60(12):1371-1382. https://doi.org/10.1016/j.addr.2008.04.009

4. Cordier D, Forrer F, Bruchertseifer F, Morgenstern A, Apostolidis C, Good S, Müller-Brand J, Mäcke H, Reubi JC, Merlo A (2010) Targeted alpha-radionuclide therapy of functionally critically located gliomas with ${ }^{213} \mathrm{Bi}$-DOTA-[Thi ${ }^{8}, \operatorname{Met}\left({ }_{0} 2^{21} 1\right]$-substance P: a pilot trial. Eur J Nucl Med Mol Imaging 37(7):1335-1344. https://doi.org/10.1007/s00259-010-1385-5

5. Morgenstern A, Bruchertseifer F, Apostolidis C (2011) Targeted alpha therapy with ${ }^{213} \mathrm{Bi}$. Curr Radiopharm 4(4):295-305. https:// doi.org/10.2174/1874471011104040295

6. Price EW, Orvig C (2014) Matching chelators to radiometals for radiopharmaceuticals. Chem Soc Rev 43(1):260-290. https://doi. org/10.1039/C3CS60304K

7. Kratochwil C, Giesel FL, Bruchertseifer F, Mier W, Apostolidis C, Boll R, Murphy K, Haberkorn U, Morgenstern A (2014) ${ }^{213} \mathrm{Bi}-$ DOTATOC receptor-targeted alpha-radionuclide therapy induces remission in neuroendocrine tumours refractory to beta radiation: a first-in-human experience. Eur J Nucl Med Mol Imaging 41(11):2106-2119. https://doi.org/10.1007/s00259-014-2857-9

8. Kratochwil C, Afshar-Oromieh A, Kopka K, Haberkorn U, Giesel FL (2016) Current status of prostate-specific membrane antigen targeting in nuclear medicine: clinical translation of chelator containing prostate-specific membrane antigen ligands into diagnostics and therapy for prostate cancer. Semin Nucl Med 
46(5):405-418. https://doi.org/10.1053/j.semnuclmed.2016.04. 004

9. Thiele NA, Wilson JJ (2018) Actinium-225 for targeted $\alpha$ therapy: coordination chemistry and current chelation approaches. Cancer Biother Radiopharm 33(8):336-348. https://doi.org/10.1089/cbr. 2018.2494

10. Morgenstern A, Apostolidis C, Kratochwil C, Sathekge M, Krolicki L, Bruchertseifer F (2018) An overview of targeted alpha therapy with ${ }^{225}$ actinium and ${ }^{213}$ bismuth. Curr Radiopharm 11(3):200-208. https://doi.org/10.2174/1874471011666180502104524

11. Tafreshi NK, Doligalski ML, Tichacek CJ, Pandya DN, Budzevich MM, El-Haddad G, Khushalani NI, Moros EG, McLaughlin ML, Wadas TJ, Morse DL (2019) Development of targeted alpha particle therapy for solid tumors. Molecules 24(23):4314. https://doi. org/10.3390/molecules24234314

12. Milenic DE, Brechbiel MW (2004) Targeting of radio-isotopes for cancer therapy. Cancer Biol Ther 3(4):361-370. https://doi. org/10.4161/cbt.3.4.790

13. Tomassoli I, Gündisch D (2016) Bispidine as a privileged scaffold. Curr Top Med Chem 16(11):1314-1342. https://doi.org/ 10.2174/1568026615666150915111434

14. Comba P, Kerscher M, Rück K, Starke M (2018) Bispidines for radiopharmaceuticals. Dalton Trans 47(28):9202-9220. https:// doi.org/10.1039/c8dt01108g

15. Nonat AM, Roux A, Sy M, Charbonnière LJ (2019) 2,4-Substituted bispidines as rigid hosts for versatile applications: From к-opioid receptor to metal coordination. Dalton Trans 48(44):16476-16492. https://doi.org/10.1039/c9dt03480c

16. Comba P, Jermilova U, Orvig C, Patrick BO, Ramogida CF, Rück K, Schneider C, Starke M (2017) Octadentate picolinic acid-based bispidine ligand for radiometal ions. Chem Eur J 23(63):15945-15956. https://doi.org/10.1002/chem.201702284

17. Juran S, Walther M, Stephan H, Bergmann R, Steinbach J, Kraus W, Emmerling F, Comba P (2009) Hexadentate bispidine derivatives as versatile bifunctional chelate agents for copper(II) radioisotopes. Bioconjugate Chem 20(2):347-359. https://doi. org/10.1021/bc800461e

18. Stephan H, Walther M, Fähnemann S, Ceroni P, Molloy JK, Bergamini G, Heisig F, Müller CE, Kraus W, Comba P (2014) Bispidines for dual imaging. Chem Eur J 20(51):17011-17018. https://doi.org/10.1002/chem.201404086

19. Singh G, Zarschler K, Hunoldt S, Martínez IIS, Ruehl CL, Matterna M, Bergmann R, Máthé D, Hegedüs N, Bachmann M, Comba P, Stephan H (2020) Versatile bispidine-based bifunctional chelators for ${ }^{64} \mathrm{Cu}^{\mathrm{II}}$-labelling of biomolecules. Chem Eur J 26(9):1989-2001. https://doi.org/10.1002/chem.201904654

20. Choudhary N, Dimmling A, Wang X, Southcott L, Radchenko V, Patrick BO, Comba P, Orvig C (2019) Octadentate oxinearmed bispidine ligand for radiopharmaceutical chemistry. Inorg Chem 58(13):8685-8693. https://doi.org/10.1021/acs. inorgchem.9b01016

21. Ndiaye D, Sy M, Pallier A, Même S, de Silva I, Lacerda S, Nonat AM, Charbonnière LJ, Tóth É (2020) Unprecedented kinetic inertness for a $\mathrm{Mn}^{2+}$-bispidine chelate: a novel structural entry for $\mathrm{Mn}^{2+}$-based imaging agents. Angew Chem Int Ed 59(29):11958-11963. https://doi.org/10.1002/anie.202003685

22. Comba P, Schiek W (2003) Fit and misfit between ligands and metal ions. Coord Chem Rev 238-239:21-29. https://doi.org/ 10.1016/S0010-8545(02)00294-1

23. Comba P, Morgen M, Wadepohl H (2013) Tuning of the properties of transition-metal bispidine complexes by variation of the basicity of the aromatic donor groups. Inorg Chem 52(11):6481-6501. https://doi.org/10.1021/ic4004214

24. Comba P, Hunoldt S, Morgen M, Pietzsch J, Stephan H, Wadepohl $\mathrm{H}$ (2013) Optimization of pentadentate bispidines as bifunctional chelators for ${ }^{64} \mathrm{Cu}$ positron emission tomography (PET). Inorg Chem 52(14):8131-8143. https://doi.org/10.1021/ic4008685

25. Roux A, Nonat AM, Brandel J, Hubscher-Bruder V, Charbonnière $\mathrm{LJ}$ (2015) Kinetically inert bispidol-based $\mathrm{Cu}$ (II) chelate for potential application to ${ }^{64 / 67} \mathrm{Cu}$ nuclear medicine and diagnosis. Inorg Chem 54(9):4431-4444. https://doi.org/10.1021/acs.inorgchem.5b00207

26. Comba P, Grimm L, Orvig C, Rück K, Wadepohl H (2016) Synthesis and coordination chemistry of hexadentate picolinic acid based bispidine ligands. Inorg Chem 55(24):12531-12543. https:// doi.org/10.1021/acs.inorgchem.6b01787

27. Roux A, Gillet R, Huclier-Markai S, Ehret-Sabatier L, Charbonnière LJ, Nonat AM (2017) Bifunctional bispidine derivatives for copper-64 labelling and positron emission tomography. Org Biomol Chem 15(6):1475-1483. https://doi.org/10.1039/c6ob02712a

28. Bruchertseifer F, Comba P, Martin B, Morgenstern A, Notni J, Starke M, Wadepohl H (2020) First-generation bispidine chelators for ${ }^{213} \mathrm{Bi}^{\mathrm{III}}$ radiopharmaceutical applications. ChemMedChem 15(16):1591-1600. https://doi.org/10.1002/cmdc.202000361

29. Frisch MJ, Trucks GW, Schlegel HB, Scuseria GE, Robb MA, Cheeseman JR, Scalmani G, Barone V, Mennucci B, Petersson GA, Nakatsuji H, Caricato M, Li X, Hratchian HP, Izmaylov AF, Bloino J, Zheng G, Sonnenberg JL, Hada M, Ehara M, Toyota K, Fukuda R, Hasegawa J, Ishida M, Nakajima T, Honda Y, Kitao O, Nakai H, Vreven T, Montgomery Jr JA, Peralta JE, Ogliaro F, Bearpark M, Heyd JJ, Brothers E, Kudin KN, Staroverov VN, Keith T, Kobayashi R, Normand J, Raghavachari K, Rendell A, Burant JC, Iyengar SS, Tomasi J, Cossi M, Rega N, Millam JM, Klene M, Knox JE, Cross JB, Bakken V, Adamo C, Jaramillo J, Gomperts R, Stratmann RE, Yazyev O, Austin AJ, Cammi R, Pomelli C, Ochterski JW, Martin RL, Morokuma K, Zakrzewski VG, Voth GA, Salvador P, Dannenberg JJ, Dapprich S, Daniels AD, Farkas O, Foresman JB, Ortiz JV, Cioslowski J, Fox DJ (2010) Gaussian 09, revision D.01. Gaussian, Inc., Wallingford CT

30. Tao J, Perdew JP, Staroverov VN, Scuseria GE (2003) Climbing the density functional ladder: Nonempirical meta-generalized gradient approximation designed for molecules and solids (TPSSTPSS). Phys Rev Lett 91(14):146401. https://doi.org/10. 1103/PhysRevLett.91.146401

31. Regueiro-Figueroa M, Esteban-Gómez D, de Blas A, RodríguezBlas T, Platas-Iglesias C (2014) Understanding stability trends along the lanthanide series. Chem Eur J 20:3974-3981. https:// doi.org/10.1002/chem.201304469

32. Roca-Sabio A, Regueiro-Figueroa M, Esteban-Gómez D, de Blas A, Rodríguez-Blas T, Platas-Iglesias C (2012) Density functional dependence of molecular geometries in lanthanide(III) complexes relevant to bioanalytical and biomedical applications. Comput Theor Chem 999:93-104. https://doi.org/10.1016/j. comptc.2012.08.020

33. Thiele NA, Woods JJ, Wilson JJ (2019) Implementing f-block metal ions in medicine: Tuning the size selectivity of expanded macrocycles. Inorg Chem 58(16):10483-10500. https://doi.org/ 10.1021/acs.inorgchem.9b01277

34. Kovács A (2020) Theoretical study of actinide complexes with Macropa. ACS Omega 5(41):26431-26440. https://doi.org/10. 1021/acsomega.0c02873

35. Kovács A (2021) Theoretical study of actinide(III)-DOTA complexes. ACS Omega 6(20):13321-13330. https://doi.org/ 10.1021/acsomega.1c01292

36. Bergner A, Dolg M, Küchle W, Stoll H, Preuss H (1993) Ab initio energy-adjusted pseudopotentials for elements of groups 13-17. Mol Phys 80(6):1431-1441. https://doi.org/10.1080/ 00268979300103121

37. Metz B, Stoll H, Dolg M (2000) Small-core multiconfigurationDirac-Hartree-Fock-adjusted pseudopotentials for post-d main group elements: application to $\mathrm{PbH}$ and $\mathrm{PbO}$. J Chem Phys 113(7):2563-2569. https://doi.org/10.1063/1.1305880 
38. Peterson KA (2003) Systematically convergent basis sets with relativistic pseudopotentials. I. Correlation consistent basis sets for the post-d group 13-15 elements. J Chem Phys 119(21):11099-11112. https://doi.org/10.1063/1.1622923

39. Grimme S, Antony J, Ehrlich S, Krieg H (2010) A consistent and accurate $a b$ initio parameterization of density functional dispersion correction (DFT-D) for the 94 elements $\mathrm{H}-\mathrm{Pu}$. J Chem Phys 132:154104. https://doi.org/10.1063/1.3382344

40. Grimme S, Ehrlich S, Goerigk L (2011) Effect of the damping function in dispersion corrected density functional theory. J Comp Chem 32:1456-1465. https://doi.org/10.1002/jcc.21759

41. Cao X, Dolg M (2001) Valence basis sets for relativistic energyconsistent small-core lanthanide pseudopotentials. J Chem Phys 115:7348-7355. https://doi.org/10.1063/1.1406535

42. Cao X, Dolg M (2002) Segmented contraction scheme for smallcore lanthanide pseudopotential basis sets. J Mol Struct (Theochem) 581:139-147. https://doi.org/10.1016/S0166-1280(01)00751-5

43. Küchle W, Dolg M, Stoll H, Preuss H (1994) Energy-adjusted pseudopotentials for the actinides. Parameter sets and test calculations for thorium and thorium monoxide. J Chem Phys 100(10):7535-7542. https://doi.org/10.1063/1.466847

44. Cao X, Dolg M, Stoll H (2003) Valence basis sets for relativistic energy-consistent small-core actinide pseudopotentials. J Chem Phys 118:487-496. https://doi.org/10.1063/1.1521431

45. Moritz A, Cao X, Dolg M (2007) Quasirelativistic energyconsistent $5 \mathrm{f}$-in-core pseudopotentials for trivalent actinide elements. Theor Chem Acc 117:473-481. https://doi.org/10.1007/ s00214-006-0180-7

46. Bader RFW (1990) Atoms in molecules. Oxford University Press, Oxford, A quantum theory

47. Rodríguez JJ, Köster AM, Ayers PW, Santos-Valle A, Vela A, Merino G (2009) An efficient grid-based scheme to compute QTAIM atomic properties without explicit calculation of zeroflux surfaces. J Comput Chem 30:1082-1092. https://doi.org/10. $1002 / j \mathrm{jcc} .21134$

48. Rodríguez JJ, Bader RFW, Ayers PW, Michel C, Götz AW, Bo C (2009) A high performance grid-based algorithm for computing QTAIM properties. Chem Phys Letters 472:149-152. https://doi. org/10.1016/j.cplett.2009.02.081

49. Lu T, Chen F (2012) Multiwfn: a multifunctional wavefunction analyzer. J Comput Chem 33(5):580-592. https://doi.org/10.1002/ jcc. 22885

50. Boys SF, Bernardi F (1970) The calculation of small molecular interactions by the differences of separate total energies. Some procedures with reduced errors. Mol Phys 19:553-566. https:// doi.org/10.1080/00268977000101561
51. Tomasi J, Mennucci B, Cammi R (2005) Quantum mechanical continuum solvation models. Chem Rev 105:2999-3093. https:// doi.org/10.1021/cr9904009

52. Scalmani G, Frisch MJ (2010) Continuous surface charge polarizable continuum models of solvation. I. General formalism. J Chem Phys 132:114110. https://doi.org/10.1063/1.3359469

53. Marenich AV, Cramer CJ, Truhlar DG (2009) Universal solvation model based on solute electron density and on a continuum model of the solvent defined by the bulk dielectric constant and atomic surface tensions. J Phys Chem B 113(18):6378-6396. https://doi. org/10.1021/jp810292n

54. Kepp KP (2018) Thermochemically consistent free energies of hydration for di- and trivalent metal ions. J Phys Chem A 122(37):7464-7471. https://doi.org/10.1021/acs.jpca.8b06674

55. Martin RL, Hay PJ, Pratt LR (1998) Hydrolysis of ferric ion in water and conformational equilibrium. J Phys Chem A 102(20):3565-3573. https://doi.org/10.1021/jp980229p

56. Shamov GA, Schreckenbach G (2005) Density functional studies of actinyl aquo complexes studied using small-core effective core potentials and a scalar four-component relativistic method. J Phys Chem A 109(48):10961-10974. https://doi.org/10.1021/jp053522f

57. Shannon RD (1976) Revised effective ionic radii and systematic studies of interatomic distances in halides and chalcogenides. Acta Cryst A32:751-767. https://doi.org/10.1107/S0567739476001551

58. Allred AL, Rochow EG (1958) A scale of electronegativity based on electrostatic force. J Inorg Nucl Chem 5(4):264-268. https:// doi.org/10.1016/0022-1902(58)80003-2

59. Little EJ, Jones MM (1960) A complete table of electronegativities. J Chem Educ 37(5):231-232. https://doi.org/10.1021/ed037p231

60. Marcus Y (1991) Thermodynamics of solvation of ions. Part 5.-Gibbs free energy of hydration at 298.15 K. J Chem Soc Faraday Trans 87(18):2995-2999. https://doi.org/10.1039/ft9918702995

61. Kelly CP, Cramer CJ, Truhlar DG (2006) Aqueous solvation free energies of ions and ion-water clusters based on an accurate value for the absolute aqueous solvation free energy of the proton. J Phys Chem B 110(32):16066-16081. https://doi.org/10.1021/jp063552y

62. Schreckenbach G (2017) Differential solvation. Chem Eur J 23(16):3797-3803. https://doi.org/10.1002/chem.201604075

Publisher's Note Springer Nature remains neutral with regard to jurisdictional claims in published maps and institutional affiliations. 